\title{
Evaluation of Irrigation Performance at Tertiary Level (A Case Study in Padi Pomahan Irrigation Area Mojokerto East Java)
}

\author{
Mohamad Bagus Ansori ${ }^{1,{ }^{*}}$, Nastasia Festy Margini ${ }^{1}$, Danayanti Azmi Dewi Nusantara ${ }^{1}$, Nadjadji Anwar ${ }^{1}$ \\ ${ }^{I}$ Department of Civil Engineering, Institut Teknologi Sepuluh Nopember Surabaya, Indonesia. \\ *Corresponding author: bagus.ansori@ce.its.ac.id
}

\begin{abstract}
Padi Pomahan Irrigation Area has a lack of sufficient amount of water at the downstream area in dry season. This problem is caused by some factors such as the exploitation of drinking water, climate change, land use change, and the damage of irrigation channel. The performance of irrigation channel and its facilities compared with the situation nearly 20 years later has never been evaluated and measured due to the limited of the preliminary data. With the area of 4309 hectares managed by two offices (UPT Pugeran and UPT Tangunan), the coordination become more complex to manage the irrigation water in this area. This paper aims to analyze the irrigation performance at tertiary level to measure the performance of six indicators/criterions such as physical infrastructure, plant productivity, personnel organization, operation and maintenance (OM), documentation, and institutional condition of water user associations (P3A / GP3A / IP3A). The results of its performance are expected to obtain the handling priority at the tertiary level in this irrigation system by Indonesian government. The total irrigation performance In Padi Pomahan obtains 61.0\%. The result model of AHP (Analytic Hierarchy Process) obtains the result of personnel organization $28.9 \%$ (rank 1), plant productivity $20.3 \%$ (rank 2), physical infrastructures $16.8 \%$ (rank 3), operation and maintenance (OM 14.2\% (rank 4), institutional condition of water user associations ( P3A / GP3A / IP3A) 10.5\% (rank 5) and documentation 9.3\% (rank 6). The ARP model obtains CGI value 0.13 and Consistency Ratio (CR) 0.036 .
\end{abstract}

Keywords—Padi Pomahan, irrigation performance, tertiary level

\section{INTRODUCTION}

\section{A \\ t present, the population of Indonesia reached 263.1}

million (May 2017), with Indonesian population growth rate reached $1.2 \%$. East Java Province as one of the granary area in Indonesia has the important part to support the national supply food. But Indonesia still has problems of the self-sufficiency of foods specially paddy due to the problem of land use change, climate change, water resources and its facilities.

Natural resources in Indonesia become one of the vital resources which absolutely necessary for the living things. To protect the sustainability of natural resources and its infrastructure, it is necessary to manage the natural resources that include three functions, the conservation of natural resources, the utilization of natural resources and the control of damaged water. The implementation of its three functions have been generated various types of water resources facilities and infrastructures. It is realized that the performance of its facilities and infrastructures was decreased from beginning and will reduce the design life of the water resources infrastructure plan. This is largely due to the fact that the process of SIDCOM (survey, investigation, design, operation and maintenance) is generally not fully consistent. Many of the water resources infrastructures in Indonesia nowadays have a lacked sufficient of maintenance, make the infrastructure rapidly decreases of its function. Therefore, almost all water resources infrastructures in Indonesia could not operate in accordance with the planned objectives.

Operation and Maintenance of Irrigation infrastructure is one of the water resources management activities which consists of two interrelated activities that aims to protect the function of sustainability and optimize the benefits of natural resources for the community and life in general. Operation and Maintenance of Irrigation infrastructure in Indonesia still become first priority to support all the irrigation system to work effective and efficient. However, since the beginning until present, the irrigation performance of all Indonesian irrigation areas has never been measured/evaluated. Therefore, the government launched the action to care about operation and maintenance called GCinOP in 2016. One of the irrigation area that be measured is Padi Pomahan.

Padi Pomahan Irrigation Area located in Mojokerto, East Java with the area of 4309 ha, that has some problems of water distribution. In dry season Padi Pomahan has a lack of sufficient amount of water at the downstream area. This problem is caused by some factors such as the exploitation for drinking water in the upstream area, climate change, land use change, and the damage of irrigation channels. The performance of irrigation channels and its facilities compared with the situation nearly 20 years later has never be measured due to the lack of the preliminary data. Padi Pomahan handled/managed by two office (UPT Pugeran and UPT Tangunan), make the coordination become more complex to manage the irrigation water in this area. 
Irrigation Performance surroundings of the Ministry of Public Works and Housing, Directorate General of Water Resources has been set with the regulation no. 32/PRT/M/2007. Irrigation performance are grouped into 6 (six) indicators such as physical infrastructures, plant productivity, personnel organization, operation and maintenance $(\mathrm{OM}), \quad$ documentation, and institutional condition of water user associations (P3A / GP3A / IP3A). This paper aims to analyze the irrigation performance at tertiary level to measure the performance of that six indicators. The results of its performance are expected to get the handling priority at the tertiary level in this irrigation system by Indonesian government.

\section{METHOD}

\section{A. Description of the Study Area}

Location of this research is Padi Pomahan Irigation Area located in Mojokerto, East Java province. The total irrigation area based on Ministry of Public Works and Housing data is 4309 ha (fig. 1). The entire area is dominated by a dam on the Pikatan River from which irrigation water is conveyed through abandoned river channels to a hierarchic irrigation network composed of primary, secondary and tertiary canals. Primary canals are divided into five independent secondary canal units through control structures. The tertiary canals serve tertiary blocks, of which 96 exist in the two administrative zones together (Pugeran and Tangunan). In a tertiary block, field canals deliver the water to the rice field and evacuate it to a hierarchic drainage network. All irrigation and drainage canals agricultural water are unlined and then directly flow the remaining water to the nearest river/primary or secondary channel.

Allocation of plots is such that irrigation canals are often shared by two or three farmers called P3AI/GP3AI/IP3AI. The principal crop is paddy rice grown during the rainy season (May-September). A second rice crop and vegetables (mostly maize) are grown during the dry season on a limited surface. The main rice-growing season sets off at the end of May with the installation of seedbeds. Rice transplanting begins gradually by mid-June and continues until the end of September. The peak irrigation demand falls during the month of September, when over $90 \%$ of the cultivated surface is irrigated and the rainy season reaches its end. The first fields are harvested already by mid-September.

\section{B. Performance Indicators}

To measure irrigation performance in Padi Pomahan Area begins with survey investigation. Survey investigation in this study was conducted to obtain the overall performance based on the six criteria. The study Diagram is shown in figure 2. Diagram of the latent variable of that criteria and scalable performance level which used in this research is described in figure 3.

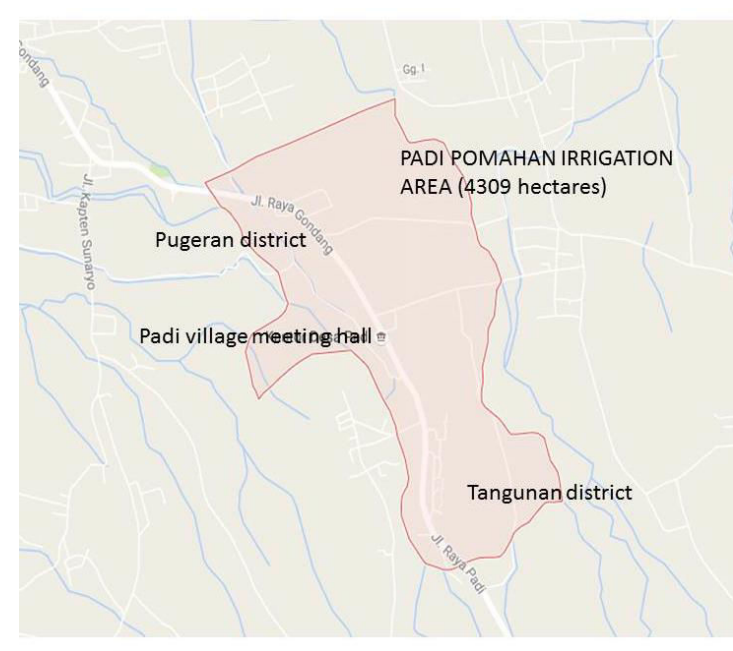

Figure 1. Padi Pomahan Irrigation Area

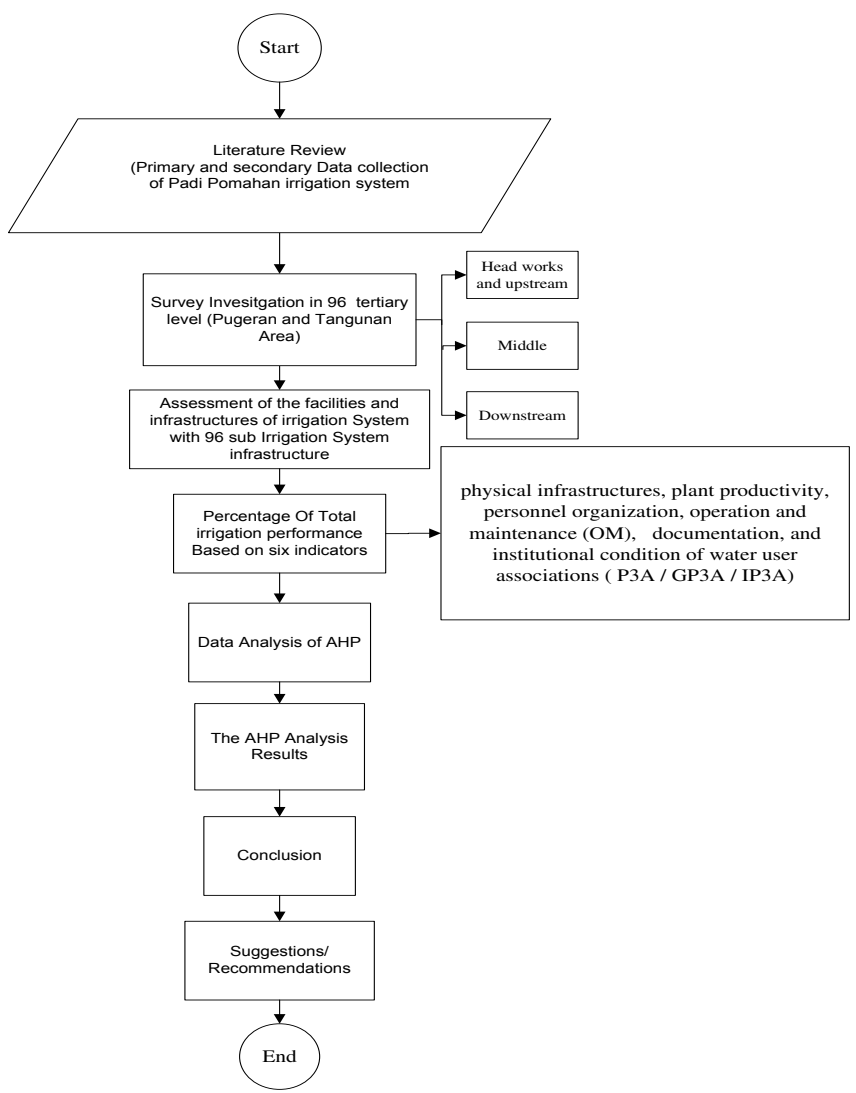

Figure 2. Flowchart Design 


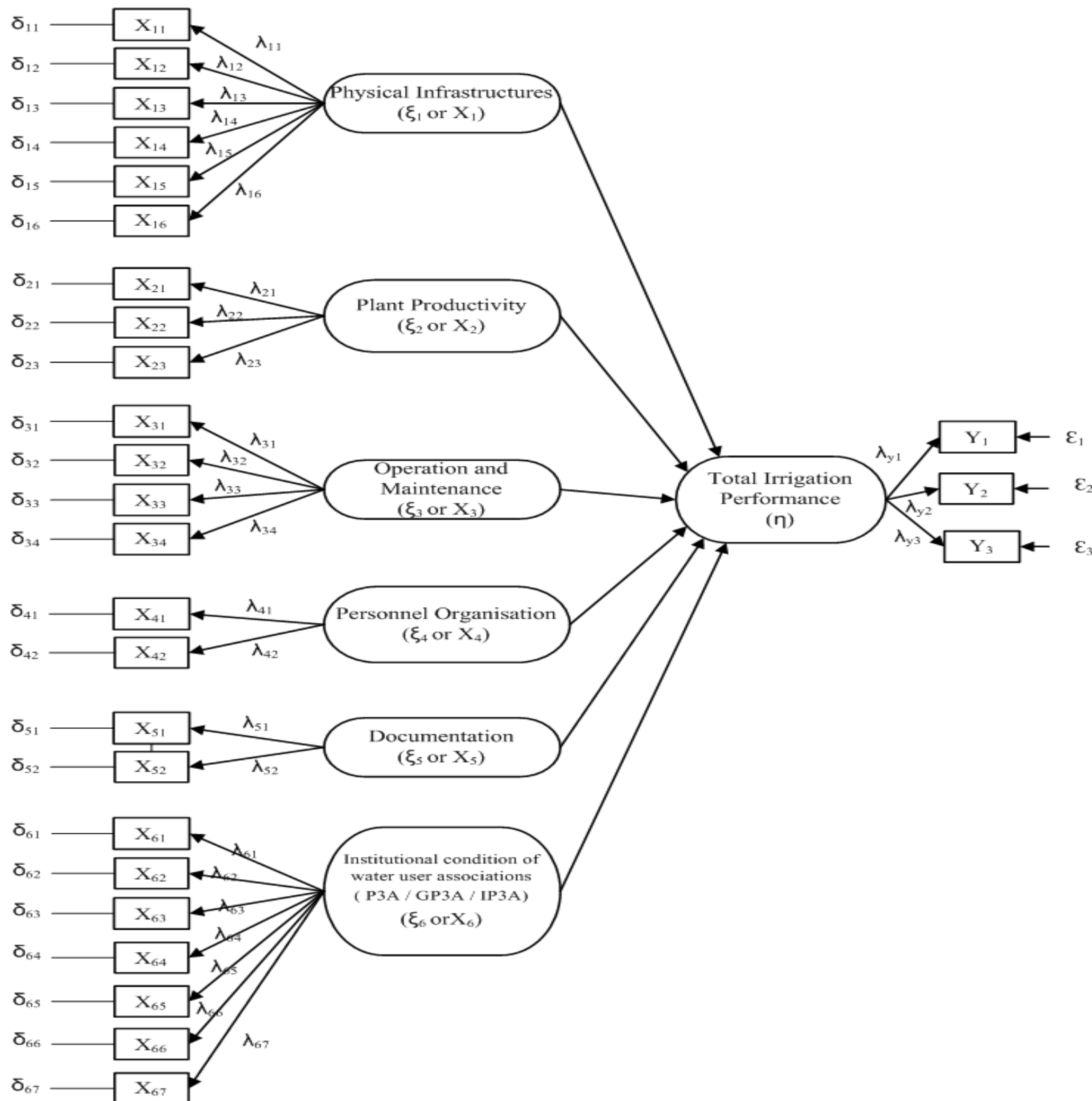

Figure 3. Criterions of Irrigation Performance

Criteria for the irrigation performance based on Ministry of public works regulation No. 32/PRT/M/2007 are described as follows:

1. The performance between $80 \%-100 \%$ is excellent/very good performance

2. The performance between $70 \%-79 \%$ is good performance

3. The performance between $55 \%-69 \%$ is adequate performance

4. The performance $<54 \%$ is less performance and need attention

From the result of survey investigation, overall performance result then become the input data for AHP (Analytic Hierarchy Process) (Goepel, Klaus D,2013).

Priorities in each input are calculated using the Row Geometric Mean Method (RGMM), with the pairwise N $\mathrm{x} N$ comparison matric $\mathrm{A}=\mathrm{a}_{\mathrm{ij}}$

$$
\begin{gathered}
r_{i}=\exp \left[\frac{1}{N} \sum_{j=1}^{N} \ln \left(a_{i j}\right)\right]=\left(\prod_{i=1}^{N} a_{i j}\right)^{1 / N} \\
p_{i}=r_{i} / \sum_{i=1}^{N} r_{i}
\end{gathered}
$$

To find the most inconsistent comparison, it calculated for the pair i,j with:

$$
\max \left(\varepsilon_{i j}=a_{i j} \frac{p_{j}}{p_{i}}\right)
$$

Consistency ratios are calculated in all input sheets and in the summary sheet. With $\lambda$ max the calculated principal eigenvalue-either based on the priority eigenvector derived from RGMM in the input sheet or derived from EVM in the summary sheet. The consistency index $\mathrm{CI}$ is given as: 


$$
\begin{gathered}
\mathrm{CI}=\frac{(\lambda \max -\mathrm{N})}{\mathrm{N}-1} \\
C R=\frac{\mathrm{CI}}{\mathrm{RI}}
\end{gathered}
$$

The consistency ratio $\mathrm{CR}$ in this AHP is calculating using Alonso/Lamata linear.

$$
\mathrm{CR}=\frac{(\lambda \max -\mathrm{N})}{2.7699 \mathrm{~N}-4.3513-\mathrm{N}}
$$

(Alonso, Lamata, 2006).

Geometric consistency index (GCI) is calculated using:

$$
\mathrm{CGI}=\frac{2 \sum_{i<j}^{N} \ln a_{i j}-\ln \frac{p_{i}}{p_{j}}}{(\mathrm{~N}-1)(\mathrm{N}-2)}
$$

$$
C_{i j}=\exp \frac{\sum_{k=1}^{N} \mathrm{wk} \cdot \ln a_{i j(k)}}{\sum_{k=1}^{N} \mathrm{wk}}
$$

\section{RESULTS AND DISCUSSION}

\section{A. Irrigation Performance}

Assessment of irrigation performance at tertiary level in Padi Pomahan irrigation area is done by tracing irrigation network. The results of its performance cover 6 aspects i.e. physical infrastructures, plant productivity, personnel organization, operation and maintenance (OM), documentation, and institutional condition of water user associations ( P3A / GP3A / IP3A) are shown in table 1. Physical infrastructures criteria include assessment of tertiary channels (channels dimension, embankments), tertiary boxes, complementary buildings (syphon, gutters, bridges, weirs, farm roads, and drainage channels. The assessment of physical infrastructure has

\begin{tabular}{|c|c|c|c|c|c|c|c|c|}
\hline \multirow[t]{2}{*}{ No } & \multirow[t]{2}{*}{$\begin{array}{l}\text { Tertiary } \\
\text { Channels }\end{array}$} & \multirow{2}{*}{$\begin{array}{c}\text { Physical } \\
\text { Infrastructures } \\
\text { Weights } 45 \% \\
\end{array}$} & \multirow{2}{*}{$\begin{array}{c}\begin{array}{c}\text { Plant } \\
\text { Productivity }\end{array} \\
\text { Weights 10\% } \\
\end{array}$} & \multirow{2}{*}{$\begin{array}{c}\begin{array}{c}\text { Operation and } \\
\text { Maintenance } \\
(\mathrm{OM})\end{array} \\
\text { Weights 20\% } \\
\end{array}$} & \multirow{2}{*}{$\begin{array}{c}\begin{array}{c}\text { Personnel } \\
\text { Organisation }\end{array} \\
\text { Weighst 5\% } \\
\end{array}$} & \multirow{2}{*}{$\begin{array}{c}\text { Documentation } \\
\text { Weights 5\% } \\
\end{array}$} & \multirow[t]{2}{*}{$\begin{array}{c}\text { Institutional } \\
\text { Condition of } \\
\text { Water User } \\
\text { Associations } \\
\text { (P3A / GP3A / } \\
\text { IP3A) } \\
\text { Weights 15\% } \\
\end{array}$} & \multirow{2}{*}{$\begin{array}{c}\begin{array}{c}\text { Total Irrigation } \\
\text { Performance }\end{array} \\
\text { Criterion x Weights }\end{array}$} \\
\hline & & & & & & & & \\
\hline 1 & BTA $1-20$ & 63.3 & 65.3 & 65.8 & 75.0 & 38.7 & 30.6 & 58.4 \\
\hline 2 & BML 1 & 71.6 & 79.0 & 85.8 & 82.5 & 38.3 & 28.5 & 67.6 \\
\hline 3 & BR 1-17 & 76.9 & 48.0 & 40.5 & 75.0 & 36.0 & 21.0 & 56.2 \\
\hline 4 & TL 1-14 & 62.1 & 82.0 & 79.2 & 68.0 & 20.0 & 53.3 & 64.4 \\
\hline 5 & KE 1-5 & 54.3 & 74.0 & 49.2 & 82.5 & 20.0 & 58.1 & 55.5 \\
\hline 6 & DL 1 & 66.4 & 74.0 & 49.2 & 82.5 & 20.0 & 58.1 & 61.0 \\
\hline 7 & NG $1-5$ & 74.6 & 74.0 & 49.2 & 82.5 & 20.0 & 58.1 & 64.6 \\
\hline 8 & PH 1-9 & 65.8 & 74.0 & 49.2 & 82.5 & 20.0 & 58.1 & 60.7 \\
\hline \multicolumn{2}{|c|}{ Average } & 66.9 & 71.3 & 58.5 & 78.8 & 26.6 & 45.7 & 61.0 \\
\hline
\end{tabular}
the highest percentage $(45 \%)$ as a determinant factor for the overall irrigation performance. Assessment of plant productivity $(10 \%)$ consists of the fulfillment of water

Table 1. Total Irrigation Performance at Tertiary Level in Padi Pomahan

Table 2. AHP Summary Result

\begin{tabular}{ccccc}
\hline No & Criterion & Comment & Weights & Rank \\
\hline 1 & Criterion 1 & Physical Infrastructures & $16.80 \%$ & $\mathbf{3}$ \\
\hline 2 & Criterion 2 & Plant Productivity & $20.30 \%$ & $\mathbf{2}$ \\
\hline 3 & Criterion 3 & Operation and Maintenance (OM) & $14.20 \%$ & $\mathbf{4}$ \\
\hline 4 & Criterion 4 & Personnel Organisation & $28.90 \%$ & $\mathbf{1}$ \\
\hline 5 & Criterion 5 & Documentation & $9.30 \%$ & $\mathbf{6}$ \\
\hline 6 & Criterion 6 & $\begin{array}{c}\text { Institutional Condition of Water User } \\
\text { Associations (P3A / GP3A / IP3A) }\end{array}$ & $10.50 \%$ & $\mathbf{5}$ \\
\hline
\end{tabular}


demand, realization of planting area, and average rice production. Operating and maintenance conditions (20\%) are determined by the completeness of the OM documents, the shift of the water distribution at small discharge, water seepage at the channel. Personnel organization $(5 \%)$ determined by the completeness of the technical officers who help the farmers. Documentation assessment $(5 \%)$ includes irrigation schemes maps, organizational administrative books, tertiary OM manuals, planting schedules and patterns, administrative and topography maps, socio-hydro maps. While the institutional condition of water user associations ( P3A / GP3A / IP3A) (15\%) is determined by the existing conditions of the farmers. The result of survey investigation would be combined with worksheet questionnaire form from Ministry of Public Works and Housing.

\section{B. Result of AHP (Analytic Hierarchy Process) Model}

The results of survey investigation become the input of AHP Model. In this AHP model consists of six criterions. Numbers of participants are the number of tertiary channel in sub area of Padi Pomahan. The ranking could be determined in each subarea and all summary of the model. In each input fill the weight/intensity from 1-9 for the evaluation.

a. Intensity 1 is equal importance means two elements contribute equally to the objective/criterion.

b. Intensity 3 is moderate importance means experience and judgment slightly favor one element over another

c. Intensity 5 is strong performance means experience and judgment strongly favor one element over another

d. Intensity 7 is very strong importance means one element favored very strongly over another.

e. Intensity 9 is extreme importance means the evidence favoring one element over another is of the highest possible order of affirmation.

f. Intensity $2,4,6,8$ can be used to express intermediate values.

The result model of AHP (Analytic Hierarchy Process) obtain as shown in table 2, with the result personnel organization $28.9 \%$ (rank 1), plant productivity $20.3 \%$ (rank 2), physical infrastructures $16.8 \%$ (rank 3), operation and maintenance (OM 14.2\% (rank 4), institutional condition of water user associations ( P3A / GP3A / IP3A) 10.5\% (rank 5) and documentation 9.3\% (rank 6). The ARP model obtains CGI value 0.13 and Consistency Ratio (CR) 0.036.

Personnel organization is ranked first because of the current organizational structures of Padi Pomahan irrigation area are still quite complete and running well. The plant productivity is ranked second because farmers are still looking for the fulfillment water supply from ground water pumping even though physical infrastructures and operation/maintenance ranks third and fourth with adequate percentage. The institutional condition of water user associations ( P3A / GP3A /
IP3A) is ranked fifth because of the liveliness, monitoring, evaluation that are still lacking. Therefore the documentation is ranked last because from the beginning, there was no data as built drawing of irrigation channels, not updated some data schemes of irrigation, incomplete data of administrative books, plant patterning schedules, tertiary maps and socio-hydro maps.

\section{CONCLUSIONS}

1. The irrigation performance in terms of physical infrastructures, plant productivity, personnel organization, operation and maintenance (OM), documentation, and institutional condition of water user associations (P3A / GP3A / IP3A) In Padi Pomahan obtains $61.0 \%$. This percentage based the regulation of Ministry of Public Works and Housing no. 32/PRT/M/2007 belongs to adequate performance.

2. The result model of AHP (Analytic Hierarchy Process) obtains the result of personnel organization $28.9 \%$ (rank 1), plant productivity $20.3 \%$ (rank 2), physical infrastructures $16.8 \%$ (rank 3), operation and maintenance (OM 14.2\% (rank 4), institutional condition of water user associations ( P3A / GP3A / IP3A) 10.5\% (rank 5) and documentation $9.3 \%$ (rank 6). The ARP model obtain CGI value 0.13 and Consistency Ratio (CR) 0.036 .

\section{AKNOWLEDGMENTS}

The authors wish to thank the farmers and staff officer of UPT Tangunan and Pugeran Mojokerto that contributed to the data collection of this study.

\section{REFERENCES}

[1] Ministry of Public Works and Housing, Directorate General of Water Resources regulation no. 32/PRT/M/2007. Manual Operation and Maintenance of Irrigation System, Jakarta. 2007. (in Indonesia).

[2] Department of Public Works General Directorate of Irrigation, Criteria for Irrigation Design (KP) 01Irrigation System, Jakarta. 1986. (in Indonesia).

[3] Department of Public Works General Directorate of Irrigation, Criteria for Irrigation Design (KP) 05Tertiary System, Jakarta. 1986. (in Indonesia).

[4] Ishizaka A., Labib A. Review of the main developments in the analytic hierarchy process, Expert systems with Applications, 38(11) 14336 - 14345, 2011.

[5] Alonso, Lamata,. Consistency in the analytic hierarchy process: a new approach. International Journal of Uncertainty, Fuzziness and Knowledge based systems, Vol 14, No 4, 445-459. 2006

[6] Goepel, Klaus D., BPMSG AHP Excel template with multiple inputs, version $\mathrm{xx}-\mathrm{http} / / /$ bpmsg.com Singapore 2013.

[7] Goepel, Klaus D. (2013). Implementing the Analytic Hierarchy Process as a Standard Method for MultiCriteria Decision Making In Corporate Enterprises - A New AHP Excel Template with Multiple Inputs, Proceedings of the International Symposium on the Analytic Hierarchy Process 2013. 